Georgetown University Law Center

Scholarship @ GEORGETOWN LAW

2003

\title{
Justice Kennedy's Libertarian Revolution: Lawrence v. Texas
}

Randy E. Barnett

Georgetown University Law Center, rb325@law.georgetown.edu

This paper can be downloaded free of charge from:

https://scholarship.law.georgetown.edu/facpub/838

http://ssrn.com/abstract=422564

2002-2003 Cato Sup. Ct. Rev. 21-41

This open-access article is brought to you by the Georgetown Law Library. Posted with permission of the author. Follow this and additional works at: https://scholarship.law.georgetown.edu/facpub

Part of the Constitutional Law Commons, and the Sexuality and the Law Commons 


\title{
Justice Kennedy's Libertarian Revolution: Lawrence v. Texas
}

\author{
Randy E. Barnett
}

In Lawrence v. Texas, ${ }^{1}$ the Supreme Court held unconstitutional a Texas law criminalizing sexual relations between persons of the same sex. That would be reason enough to consider the case a landmark decision. But to those schooled in post-New Deal "fundamental rights" jurisprudence, what was most striking about Lawrence was the way the Court justified its ruling. If the approach the Court took in the case is followed in other cases in the future, we have in Lawrence nothing short of a constitutional revolution, with implications reaching far beyond the "personal liberty" at issue here.

Contrary to how their decision was widely reported, the Lawrence majority did not protect a "right of privacy." Instead, quite simply, they protected "liberty." Breaking free at last of the post-New Deal constitutional tension between the "presumption of constitutionality," on one hand, and "fundamental rights," on the other, Justice Anthony Kennedy and the four justices who joined his opinion did not begin by assuming the statute was constitutional. But neither did they call the liberty at issue "fundamental," which the modern Court would have been expected to do before withholding the presumption of constitutionality from the statute. Instead, the Court took the much simpler tack of requiring the state to justify its statute, whatever the status of the right at issue.

To better appreciate the significance and the implications of this major break with the recent past, it will be useful to begin not with the case but with a brief history of this "presumption of constitutionality." Reflecting on Lawrence in that larger context will show the potential the decision has-and show too how it returns us, in a fundamental way, to our first principles as a nation.

${ }^{1} 123$ S. Ct. 2472 (2003). 


\section{Constitutional Liberty Meets the "Progressive" Movement}

At the end of the 19th century, as the so-called progressive movement grew in political strength, states passed statutes regulating and restricting all manner of economic activity. At the same time, "morals" legislation became more pervasive as well, although often such laws were enacted under the rubric of "public health," a development the historian Ronald Hamowy has called the "medicalization of sin." ${ }^{2}$ All of this was part of an intellectual and political movement to improve upon the result of private, personal, and economic choices by aggressively using government power to enhance the general welfare.

As that sort of legislation gained in popularity, the Supreme Court resisted sporadically, striking down some but not all statutes restricting economic activities. Lochner v. New York was the most famous of those cases. ${ }^{3}$ There the Supreme Court struck down provisions of a state statute limiting the maximum hours bakeshop employees could work per week. The Court found the provisions violated the "liberty of contract" between employees and employers that was protected, it said, by the "liberty" portion of the Due Process Clause of the Fourteenth Amendment. In other cases, the Court struck down noneconomic legislation as well, such as state laws mandating English-only education of children ${ }^{4}$ or requiring parents to send their children to public schools, ${ }^{5}$ as arbitrary infringements of liberty.

In those cases the Court spoke simply of the liberty of the individual, then required the state to justify restricting that liberty. Not surprisingly, given their political agenda, progressives bitterly criticized the Court's use of the Due Process Clause, especially in the economic sphere, as thwarting the democratic political process. Yet only a small fraction of progressive legislation was voided. Moreover, the Supreme Court did not categorically ban such statutes. Rather, it merely required that the government justify its regulations.

${ }^{2}$ See Ronald Hamowy, Preventive Medicine and the Criminalization of Sexual Immorality in Nineteenth Century America, in Assessing the Criminal: Restitution, Retribution, And the Legal Process 33 (Randy Barnett \& John Hagel III eds., 1977).

${ }^{3} 198$ U.S. 45 (1905).

${ }^{4}$ Meyer v. Nebraska, 262 U.S. 390 (1923).

${ }^{5}$ Pierce v. Society of Sisters of the Holy Names of Jesus and Mary, 268 U.S. 510 (1925). 
Indeed, the principal problem with the Supreme Court's jurisprudence during the Progressive Era was its lack of a coherent distinction between legislation upheld and legislation stricken. Had more statutes been found unconstitutional, the results would have been easier to explain.

Critics also claimed that those cases represented a revolutionary departure from the constitutional principles of the founding, ${ }^{6}$ but their case was weak. They offered little persuasive historical evidence, and what evidence they presented ignored the structural changes wrought by the enactment of the Fourteenth Amendment. Needless to say, those critics paid no attention to the original meaning of that provision. Today, even some constitutional scholars sympathetic to economic regulation acknowledge the continuity between the principles of the founding and what the Progressive Era Supreme Court was trying to do in circumscribing state power via the Fourteenth Amendment. ${ }^{7}$

With the Great Depression and the New Deal, however, the focus shifted to progressive measures enacted at the national level. The Court struck down several of those measures as exceeding the powers of Congress under the Commerce Clause. ${ }^{8}$ Yet eventually it reversed itself and upheld that legislation as constitutional. The story of that reversal is fascinating, but too complicated to summarize here. Suffice it to say that recent research has called into question the contention that the Progressive Era Court's jurisprudence was reversed only in 1937, under pressure of Roosevelt's Court-packing scheme, by the "switch in time that saved nine. ${ }^{\prime \prime}$ Rather, as early as the beginning of the 1930s, Hoover appointees (Hoover considered himself a progressive) softened the Court's constitutional objections

\footnotetext{
${ }^{6}$ See, e.g., Walton H. Hamilton \& Douglass Adair, The Power to Govern: The Constitution-Then AND Now (1937). I respond to their historical claims in Randy E. Barnett, The Original Meaning of the Commerce Clause, 68 U. CHI. L. Rev. 101, 130-132 (2001).

${ }^{7}$ See especially Howard Gillman, The Constitution Besieged: The Rise and Demise of Lochner Era Police Powers JuRisprudence (1993).

${ }^{8}$ See, e.g., Schecter Corp. v. United States, 295 U.S. 495 (1935).

${ }^{9}$ See Barry Cushman, Rethinking the New Deal Court: The Structure of a Constitutional Revolution (1998). Cf., William E. Leuchtenburg, The Supreme Court Reform: The Constitutional Revolution in the Age of Roosevelt (1995).
} 
to progressive legislation, which had the effect of further undermining the coherence of the Court's earlier restrictive doctrines. Nevertheless, the final nail in the coffin of liberty did not come until the Supreme Court was thoroughly controlled by Roosevelt appointees in the early 1940s.

\section{Enter the Presumption of Constitutionality}

For present purposes it is significant that in 1931, years before the so-called Revolution of '37, Justice Louis Brandeis adopted a "presumption of constitutionality" when evaluating the exercise of state police powers. In $O^{\prime}$ Gorman $\&$ Young, Inc. v. Hartford Fire Insurance Co., Brandeis wrote:

The statute here questioned deals with a subject clearly within the scope of the police power. We are asked to declare it void on the ground that the specific method of regulation prescribed is unreasonable and hence deprives the plaintiff of due process of law. As underlying questions of fact may condition the constitutionality of legislation of this character, the presumption of constitutionality must prevail in the absence of some factual foundation of record for overthrowing the statute. $^{10}$

Writing glowingly of this case in the Columbia Law Review, Walton Hamilton sang the praises of Brandeis's doctrinal maneuver-highlighting in the process the radical changes to come:

The demand is to find an escape from the recent holdings predicated upon "freedom of contract" as "the rule," from which a departure is to be allowed only in exceptional cases. The occasion calls not for the deft use of tactics, but for a larger strategy. The device of presumptions is almost as old as law; Brandeis revives the presumption that acts of a state legislature are valid and applies it to statutes regulating business activity. The factual brief has many times been employed to make a case for social legislation; Brandeis demands of the opponents of legislative acts a recitation of fact showing that the evil did not exist or that the remedy was inappropriate. He appeals from precedents to more venerable precedents; reverses the rules of presumption and proof in cases involving the

${ }^{10} 282$ U.S. 251, 257-58 (1931) (emphasis added). 
control of industry; and sets up a realistic test of constitutionality. It is all done with such legal verisimilitude that a discussion of particular cases is unnecessary; it all seems obviousonce Brandeis has shown how the trick is done. It is attended with so little of a fanfare of judicial trumpets that it might have passed almost unnoticed, save for the dissenters, who usurp the office of the chorus in a Greek tragedy and comment upon the action. Yet an argument which degrades "freedom of contract" to a constitutional doctrine of the second magnitude is compressed into a single compelling paragraph. ${ }^{11}$

As O'Gorman shows, well before the so-called Revolution of '37 the Court was deferring to state legislatures. As the Brandeis quotation suggests, initially the presumption of constitutionality could be rebutted, at least in theory, by those objecting to a statute's constitutionality. By the 1940s, however, the presumption became irrebuttable for all practical purposes, at least in the case of economic regulation. Thus, in the 1956 case of Williamson v. Lee Optical, ${ }^{12}$ the Court reversed a lower court that had held unconstitutional portions of a state statute that made it unlawful "for any person not a licensed optometrist or ophthalmologist to fit lenses to a face or to duplicate or replace into frames lenses or other optical appliances, except upon written prescriptive authority of an Oklahoma licensed ophthalmologist or optometrist." ${ }^{\prime 13}$ The district court had held that such a requirement was not "reasonably and rationally related to the health and welfare of the people."14 The law thus violated the Due Process Clause by arbitrarily interfering with an optician's right to do business.

Plainly, the trial court was not playing from the post-New Deal playbook. It still believed that the presumption of constitutionality was rebuttable. Thus, it had written:

\footnotetext{
${ }^{11}$ Walton H. Hamilton, The Jurist's Art, 31 Colum. L. Rev. 1073, 1074-75 (1931) (emphases added) (footnotes omitted). Hamilton coauthored, THE POWER TO GOVERN, discussed above, supra, note 6 .

${ }^{12} 348$ U.S. 483 (1956).

${ }^{13} \mathrm{Id}$. at 485 .

${ }^{14}$ Lee Optical of Oklahoma v. Williamson, 120 F. Supp. 128, 136 (1954).
} 
It is recognized, without citation of authority, that all legislative enactments are accompanied by a presumption of constitutionality; and, that the court must not by decision invalidate an enactment merely because in the court's opinion the legislature acted unwisely. Likewise, where the statute touches upon the public health and welfare, the statute cannot be deemed unconstitutional class legislation, even though a specific class of persons or businesses is singled out, where the legislation in its impact is free of caprice and discrimination and is rationally related to the public good. A court only can annul legislative action where it appears certain that the attempted exercise of police power is arbitrary, unreasonable or discriminatory. ${ }^{15}$

No, not even then, as Roosevelt-appointee and former New Dealer Justice William O. Douglas ${ }^{16}$ explained in his opinion for a unanimous Supreme Court, reversing the wayward district court.

[T] he law need not be in every respect logically consistent with its aims to be constitutional. It is enough that there is an evil at hand for correction, and that it might be thought that the particular legislative measure was a rational way to correct it. The day is gone when this Court uses the Due Process Clause of the Fourteenth Amendment to strike down state laws, regulatory of business and industrial conditions, because they may be unwise, improvident, or out of harmony with a particular school of thought. ${ }^{17}$

Justice Douglas's opinion made clear that when restricting liberty, the legislature need not have had good reasons. It is enough that it might have had good reasons:

The legislature might have concluded that the frequency of occasions when a prescription is necessary was sufficient to justify this regulation of the fitting of eyeglasses. Likewise, ... the legislature might have concluded that one was needed

${ }^{15} I d$. at 132 (emphasis added).

${ }^{16}$ Before his appointment to the Court to succeed Justice Brandeis, Douglas was Roosevelt's nominee to chair the Securities and Exchange Commission in 1937. Prior to his appointment to the Commission, Douglas was a professor at Yale Law School. Roosevelt reportedly came close to picking Douglas as his running mate in the 1944 election.

${ }^{17} 348$ U.S. at $487-88$. 
often enough to require one in every case. Or the legislature may have concluded that eye examinations were so critical, not only for correction of vision but also for detection of latent ailments or diseases, that every change in frames and every duplication of a lens should be accompanied by a prescription from a medical expert. ... ${ }^{18}$

Consequently, Justice Douglas concluded, "[w]e cannot say that the regulation has no rational relation to that objective and therefore is beyond constitutional bounds. ${ }^{\prime 19}$ With Lee Optical as the norm, what then was left of judicial review?

Qualifying the Presumption of Constitutionality: The Theory of Footnote Four

As Lee Optical makes plain, post-New Deal deference to state legislatures and to Congress meant that courts simply would not guard against constitutional violations: "For protection against abuses by legislatures the people must resort to the polls, not to the courts, ${ }^{\prime 20}$ said Douglas. If applied consistently, this deferential attitude would obviously end the entire practice of judicial review. How then did the post-New Deal Court avoid that slippery slope? The answer is found in a single footnote that foreshadows the entire post-New Deal theory of judicial review and constitutional rights.

I allude, of course, to the famous Footnote Four of the 1938 case of United States $v$. Carolene Products Co. ${ }^{21}$ which concerned legislative restrictions on the sale of a milk substitute that competed with the products of dairy farmers. ${ }^{22}$ In the text of his opinion, Justice Harlan Fiske Stone ${ }^{23}$ strongly asserted the presumption of constitutionality.

${ }^{18}$ Id. at $477-88$ (emphases added).

${ }^{19}$ Id. at 489 .

${ }^{20} I d$. at 488 .

${ }^{21} 304$ U.S. 144 (1938).

${ }^{22}$ See Geoffrey P. Miller, The True Story of Carolene Products, 1987 Sup. CT. REv. 397.

${ }^{23}$ Although a Coolidge appointee, Justice Stone was elevated to Chief Justice by President Roosevelt in 1941, the same year Stone authored the opinion of the Court in United States v. Darby, 312 U.S. 100 (1941). That opinion definitively expanded the powers of Congress under the Commerce and Necessary and Proper clauses in the same manner as the police power of states had been enlarged in 1937 in West Coast Hotel v. Parrish, 300 U.S. 379 (1937). The 5-4 decision in West Coast Hotel, in which the Court abstained from policing the limits of the police power of the states, was among the cases that led to 1937 being identified as the year of the New Deal constitutional revolution. 
"[T]he existence of facts supporting the legislative judgment is to be presumed," he wrote,

for regulatory legislation affecting ordinary commercial transactions is not to be pronounced unconstitutional unless in the light of the facts made known or generally assumed it is of such a character as to preclude the assumption that it rests upon some rational basis within the knowledge and experience of the legislators. ${ }^{24}$

Carolene Products is famous, however, for the footnote that immediately followed that passage, ${ }^{25}$ which began as follows:

There may be a narrower scope for operation of the presumption of constitutionality when legislation appears on its face to be within a specific prohibition of the Constitution, such as those of the first ten amendments, which are deemed equally specific when held to be embraced within the Fourteenth. ${ }^{26}$

The note goes on to add two more exceptions to the presumption of constitutionality - for laws that restrict the political process, and laws that are directed at "discrete and insular minorities." ${ }^{27}$

${ }^{24}$ Carolene Prods., 304 U.S. at 152.

${ }^{25}$ The fame of this footnote is illustrated by the fact it merits its own entry in THE Oxford Companion to the Supreme Court of the United States. See Dean Alfange, Jr., Footnote Four, in OXford COMPANION 306-07 (Kermit L. Hall et al. eds., 1992).

${ }^{26} \mathrm{Id}$. at 152 n.4.

${ }^{27}$ More fully, the text of the note reads:

It is unnecessary to consider now whether legislation which restricts those political processes which can ordinarily be expected to bring about repeal of undesirable legislation, is to be subjected to more exacting judicial scrutiny under the general prohibitions of the Fourteenth Amendment than are most other types of legislation.

Nor need we enquire whether similar considerations enter into the review of statutes directed at particular religious, ... or national, ... or racial minorities ... ; whether prejudice against discrete and insular minorities may be a special condition, which tends seriously to curtail the operation of those political processes ordinarily to be relied upon to protect minorities, and which may call for a correspondingly more searching judicial inquiry.

Id. at 152-53 n.4 (citations omitted). 
After Carolene Products, legislation was presumed to be constitutional unless one of the three exceptions in Footnote Four was satisfied, in which case the Court would give the statute "heightened scrutiny." Due to the indiosyncracies of the first eight amendments, this doctrinal maneuver allowed the court to uphold economic regulations, as in Lee Optical, while preserving judicial review of such "personal" freedoms as those of speech, assembly, and press. That the personal right to bear arms, explicitly mentioned in the Second Amendment, has not been judicially protected shows the ideological nature of this maneuver, as does the uneven protection of property rights, explicitly mentioned in the Fifth Amendment.

Ironically, in recent years judicial conservatives like Robert Bork and Raoul Berger have been among the most stalwart in their allegiance to the judicial philosophy of Footnote Four. For all the reverence they express toward the Framers of the Constitution, jurisprudentially speaking, they are unreconstructed Roosevelt New Dealers.

\section{Enter the Unenumerated "Right of Privacy"}

Until the 1960s, the Supreme Court was content for the most part to confine judicial review to policing most of the enumerated rights contained in the Bill of Rights, while deferring to legislative power in all other arenas. As just noted, this post-New Deal jurisprudence of (partial) restraint is today the holy grail of judicial conservatives. Their posture came about, in part, in reaction to Griswold v. Connecti$\mathrm{cut}^{28}$ a case in which the Court considered the constitutionality of a state using its police power to ban not only the "personal" liberty to use contraceptives but also the "economic" liberty to sell and distribute them.

The Griswold Court struck down the statute for violating an unenumerated right it called the "right of privacy." The task of justifying this extension of judicial review to a right not specified in the Bill of Rights, for the first time since Carolene Products, fell to Justice Douglas, author of the Lee Optical opinion. ${ }^{29} \mathrm{He}$ did so by attempting

${ }^{28} 381$ U.S. 479 (1965).

${ }^{29}$ Douglas took pains to distinguish Griswold from Lee Optical and other cases rejecting the Due Process Clause jurisprudence of the Progressive-Era Court:

[W]e are met with a wide range of questions that implicate the Due

Process Clause of the Fourteenth Amendment. Overtones of some arguments suggest that Lochner v. New York, 198 U.S. 45, should be our guide. But we decline that invitation, as we did in West Coast Hotel Co. v. Parrish, 300 U.S. 379; Olsen v. Nebraska, 313 U.S. 236; Lincoln Union v. Northwestern Co., 335 U.S. 525; Williamson v. Lee 
to connect, however tenuously, this unenumerated right to those that are enumerated:

The foregoing cases suggest that specific guarantees in the Bill of Rights have penumbras, formed by emanations from those guarantees that help give them life and substance.... Various guarantees create zones of privacy. The right of association contained in the penumbra of the First Amendment is one, as we have seen. The Third Amendment, in its prohibition against the quartering of soldiers "in any house" in time of peace without the consent of the owner, is another facet of that privacy. The Fourth Amendment explicitly affirms the "right of the people to be secure in their persons, houses, papers, and effects, against unreasonable searches and seizures." The Fifth Amendment, in its Self-Incrimination Clause, enables the citizen to create a zone of privacy which government may not force him to surrender to his detriment. The Ninth Amendment provides: "The enumeration in the Constitution, of certain rights, shall not be construed to deny or disparage others retained by the people." ${ }^{\prime 30}$

That was probably the best he could do to reach the result in the case while ostensibly staying within the prevailing constitutional theory of Footnote Four. On the one hand, had Douglas grounded the decision in "liberty" (which is mentioned in the text) rather than "privacy" (which is not), it would have risked undoing the strong deference to Congress and state legislatures that he and his fellowNew Deal justices had previously established.

On the other hand, by narrowly construing the unenumerated right being protected, Douglas ensured that procreative rights, and later abortion rights, would be viewed as special interest rights. Had those liberties been protected as aspects of a general right to liberty, rather than based on the more narrow right to privacy, they might

\footnotetext{
Optical Co., 348 U.S. 483; Giboney v. Empire Storage Co., 336 U.S. 490.

We do not sit as a super-legislature to determine the wisdom, need, and propriety of laws that touch economic problems, business affairs, or social conditions. This law, however, operates directly on an intimate relation of husband and wife and their physician's role in one aspect of that relation.
}

Id. at 481-82. Notice the rhetoric of "super-legislature" now associated with judicial conservatives.

${ }^{30} I d$. at 484 (emphasis added). 
have received broader support from those who wanted to see their favored liberties protected as well.

Douglas's choice also provoked the debate over "judicial activism" that remains with us to this day. Like the progressives decrying the Supreme Court that decided Lochner, judicial conservatives bitterly criticized the Warren Court for its deviation from the postNew Deal jurisprudence of Footnote Four. Indeed, Stanford law professor Gerald Gunther, no political conservative, paired Griswold with Lochner in his then-leading casebook in constitutional law. ${ }^{31}$ Although his objective was to undermine the legitimacy of Griswold, it had the unintended consequence, among some, of causing a more sympathetic reconsideration of Lochner. ${ }^{32}$

\section{Enter "Fundamental Rights" v. Mere "Liberty Interests"}

Nevertheless, "emanations" and "penumbras" could not conceal the fact that the protection of an unenumerated right of privacy was outside the framework of Footnote Four. The beauty of the Footnote Four solution was that it cleanly limited judicial review to enumerated rights, while allowing government free rein in the economic sphere. The problem created by the unenumerated right of privacy, however, was that it now forced upon the Court the messy business of distinguishing those liberties, enumerated and unenumerated, that rebut the presumption of constitutionality from those that do not. The former it called "fundamental rights," while the latter were dubbed mere "liberty interests." But how to tell the difference?

Eventually the Court settled on limiting fundamental rights to those that were in its opinion "implicit in the concept of ordered liberty" and could be grounded in our "traditions and history." As Justice Byron White explained in Bowers v. Hardwick, ${ }^{33}$ the 1986 decision that upheld a Georgia statute criminalizing sodomy, which Lawrence overturned:

${ }^{31}$ See Gerald Gunther, Constitutional Law 570-646 (10th ed. 1975).

${ }^{32} \mathrm{I}$ know of Professor Gunther's authorial intentions from private correspondence with him. In my first article on constitutional law, I credited him with having rehabilitated the doctrine of substantive due process, citing his casebook. He wrote to me protesting that he was appalled at the thought that his juxtaposition of the two cases might have had the opposite effect of what he was trying to achieve.

${ }^{33} 478$ U.S. 186 (1986). 


\begin{abstract}
Striving to assure itself and the public that announcing rights not readily identifiable in the Constitution's text involves much more than the imposition of the Justices' own choice of values on the States and the Federal Government, the Court has sought to identify the nature of the rights qualifying for heightened judicial protection. In Palko v. Connecticut, ... it was said that this category includes those fundamental liberties that are "implicit in the concept of ordered liberty," such that "neither liberty nor justice would exist if [they] were sacrificed." A different description of fundamental liberties appeared in Moore v. East Cleveland, ... where they are characterized as those liberties that are "deeply rooted in this Nation's history and tradition." ... See also Griswold $v$. Connecticut. ... ${ }^{34}$
\end{abstract}

The outcome of that analysis depends almost entirely, however, on how specifically you define the right being asserted. The more specifically you define the liberty at issue-for example, a "constitutional right of homosexuals to engage in acts of sodomy"35 - the more difficult a burden this is to meet and the more easily the rights claim can be ridiculed. Although "liberty" as a general matter is obviously deeply rooted in our history and traditions, the specific liberty to use contraceptives is not. Nor are many other liberties, especially if unknown at the founding. Even liberties that existed at the founding, like the liberty of self-medication, have not to date been deemed "fundamental" by the Court.

Whenever a particular liberty is specified, therefore, it is always subject to the easy rejoinder: "Just where in the Constitution does it say that?" And that rejoinder is offered notwithstanding the plain language of the Ninth Amendment: "The enumeration in the Constitution of certain rights shall not be construed to deny or disparage others retained by the people. ${ }^{\prime \prime 36}$ With that background in mind, we are now in a position to appreciate the potentially revolutionary significance of the decision in Lawrence v. Texas.

\footnotetext{
${ }^{34} I d$. at $191-92$.

${ }^{35} \mathrm{Id}$. at 191.

${ }^{36}$ U.S. CONST. amend. IX.
} 


\section{Justice Kennedy's Crucial Switch from Privacy to Liberty}

In the 1992 abortion rights case of Planned Parenthood v. Casey, ${ }^{37}$ Justice Kennedy began to escape from the New Deal-era box in the part of the coauthored opinion that is commonly attributed to him. ${ }^{38}$ He refused there to rest abortion rights on a "right to privacy," although that crucial move has been generally ignored. Instead, he rested those rights on liberty and explicitly on the Ninth Amendment:

Neither the Bill of Rights nor the specific practices of States at the time of the adoption of the Fourteenth Amendment marks the outer limits of the substantive sphere of liberty which the Fourteenth Amendment protects. See U.S. Const., Amend. 9.9

Resting abortion rights on liberty, as opposed to privacy, was newsworthy, but little noticed. To this day, most scholars and public commentators still speak of the "right of privacy," not the "right of liberty." Until Lawrence, the question was whether this right to liberty would ever be seen again.

In Lawrence v. Texas, it has reappeared, with Justice Kennedy now writing for a majority of the Court (not including Justice O'Connor, who concurred only in the result), rather than as part of a mere trio in Casey. Liberty, not privacy, pervades this opinion like none other, beginning with the very first paragraph:

Liberty protects the person from unwarranted government intrusions into a dwelling or other private places. In our tradition the State is not omnipresent in the home. And there are other spheres of our lives and existence, outside the home, where the State should not be a dominant presence. Freedom extends beyond spatial bounds. Liberty presumes an autonomy of self that includes freedom of thought, belief, expression, and certain intimate conduct. The instant case involves liberty of the person both in its spatial and more transcendent dimensions. ${ }^{40}$

${ }^{37} 505$ U.S. 833 (1992).

${ }^{38}$ Justice Souter is credited with the discussion of stare decisis-properly ridiculed by Justice Scalia in his Lawrence dissent-and Justice O'Connor with the discussion of "undue burden."

${ }^{39} 505$ U.S. at 848 (emphasis added).

${ }^{40} 123$ S. Ct. at 2475 (emphasis added). 
Other examples abound:

We conclude the case should be resolved by determining whether the petitioners were free as adults to engage in the private conduct in the exercise of their liberty under the Due Process Clause of the Fourteenth Amendment to the Constitution. ${ }^{41}$

There are broad statements of the substantive reach of liberty under the Due Process Clause in earlier [Progressive-era] cases, including Pierce v. Society of Sisters, 268 U.S. 510 (1925), and Meyer v. Nebraska, 262 U.S. 390 (1923); but the most pertinent beginning point is our decision in Griswold v. Connecticut, 381 U.S. 479 (1965). ${ }^{42}$

Justice Kennedy puts rhetorical distance between the decision in Lawrence and the right of privacy protected in Griswold: "The Court [in Griswold] described the protected interest as a right to privacy and placed emphasis on the marriage relation and the protected space of the marital bedroom. ${ }^{\prime 43}$ Indeed, the "right of privacy" makes no other appearance in this opinion (apart from quotations from the grant of certiorari from a previous case discussing Griswold). In contrast "liberty" appears in the opinion at least twenty-five times.

Even Justice Kennedy's rejection of the argument from stare decisis rests on the centrality of liberty.

In Casey we noted that when a Court is asked to overrule a precedent recognizing a constitutional liberty interest, individual or societal reliance on the existence of that liberty cautions with particular strength against reversing course. ... The holding in Bowers, however, has not induced detrimental reliance comparable to some instances where recognized individual rights are involved. ${ }^{44}$

In Lawence $v$. Texas, therefore, liberty, not privacy, is doing all the work.

${ }^{41} I d$. at 2476 (emphasis added).

${ }^{42} I d$. (emphasis added).

${ }^{43} I d$.

${ }^{44} I d$. at 2483 . 


\section{Justice Kennedy Employs an Implicit "Presumption of Liberty"}

Lawrence is potentially revolutionary not only because it abandons a right to privacy in favor of liberty, but for another closely related reason: In the majority's opinion, there is not even the pretense of a "fundamental right" rebutting the "presumption of constitutionality." Justice Kennedy never mentions any presumption to be accorded the Texas statute.

More important, he never tries to justify the sexual liberty of samesex couples as a fundamental right. Instead, he spends all of his energies demonstrating that same-sex sexual freedom is a legitimate aspect of liberty - unlike, for example, actions that violate the rights of others, which are not liberty but license. Not only does this take the Court outside the framework of Footnote Four, it also removes it from the framework of unenumerated fundamental rights that was engrafted upon it in the wake of Griswold. Until Lawrence, every unenumerated rights case had to establish that the liberty at issue was "fundamental," as opposed to a mere liberty interest.

Justice Scalia, in dissent, takes accurate note of all of this:

Though there is discussion of "fundamental proposition[s]," ... and "fundamental decisions," ... nowhere does the Court's opinion declare that homosexual sodomy is a "fundamental right" under the Due Process Clause; nor does it subject the Texas law to the standard of review that would be appropriate (strict scrutiny) if homosexual sodomy were a "fundamental right." Thus, while overruling the outcome of Bowers, the Court leaves strangely untouched its central legal conclusion: "[R]espondent would have us announce ... a fundamental right to engage in homosexual sodomy. This we are quite unwilling to do." 478 U.S., at 191. Instead the Court simply describes petitioners' conduct as "an exercise of their liberty" - which it undoubtedly is - and proceeds to apply an unheard-of form of rational-basis review that will have far-reaching implications beyond this case. ${ }^{45}$

In other words, with liberty as the baseline, the majority places the onus on the government to justify its statutory restriction.

${ }^{45} I d$. at 2488 (Scalia, J., dissenting). 
Although he never acknowledges it, Justice Kennedy is employing here what I have called a "presumption of liberty"46 that requires the government to justify its restriction on liberty, instead of requiring the citizen to establish that the liberty being exercised is somehow "fundamental." In this way, once an action is deemed to be a proper exercise of liberty (as opposed to license), the burden shifts to the government.

All that was offered by the government to justify this statute is the judgment of the legislature that the prohibited conduct is "immoral," which for the majority (including, on this issue, Justice $\mathrm{O}^{\prime}$ Connor) is simply not enough to justify the restriction of liberty. Why not? Here the Court is content to rest its conclusion on a quote from Justice Stevens's dissenting opinion in Bowers:

Our prior cases make two propositions abundantly clear. First, the fact that the governing majority in a State has traditionally viewed a particular practice as immoral is not a sufficient reason for upholding a law prohibiting the practice; neither history nor tradition could save a law prohibiting miscegenation from constitutional attack. Second, individual decisions by married persons, concerning the intimacies of their physical relationship, even when not intended to produce offspring, are a form of "liberty" protected by the Due Process Clause of the Fourteenth Amendment. Moreover, this protection extends to intimate choices by unmarried as well as married persons. ${ }^{\prime 47}$

A stronger defense of this conclusion is possible. ${ }^{48}$ A legislative judgment of "immorality" means simply that a majority of the legislature disapproves of this conduct. But justifying legislation solely on grounds of morality would entirely eliminate judicial review of legislative powers. How could a court ever adjudicate between a legislature's claim that a particular exercise of liberty is "immoral" and a defendant's contrary claim that it is not?

In practice, therefore, a doctrine allowing legislation to be justified solely on the basis of morality would recognize an unlimited police

${ }^{46}$ See Randy E. Barnett, Restoring the Lost Constitution: The Presumption of LibERTY (Princeton, forthcoming 2004).

${ }^{47}$ Bowers, 478 U.S. at 216 (footnotes and citations omitted).

${ }^{48}$ And was offered to the Court in an amicus brief filed by the Institute for Justice, which I coauthored. 
power in state legislatures. Unlimited power is the very definition of tyranny. Although the police power of states may be broad, it was never thought to be unlimited. ${ }^{49}$

\section{Defending Lawrence from Judicial Conservatives}

Given their grounding still rooted in post-New Deal constitutional jurisprudence, the responses of judicial conservatives (not to be equated with all political conservatives) are entirely predictable. Yet each fails upon critical inspection. Three such responses stand out.

First, judicial conservatives argue that all laws restrict some freedom; thus, requiring legislatures to justify to a court their restrictions on liberty would amount to giving judges an unbridled power to strike down laws of which they disapprove. But that is to equate "liberty" and "license," a mistake the Founders never made. Liberty is and always has been the properly defined exercise of freedom. Liberty is and always has been constrained by the rights of others. No one's genuine right to liberty is violated by restricting his or her freedom to rape or murder, because there is no such right in the first place.

That is not to say that the rightful exercise of liberty may never be regulated - or made regular (as opposed to prohibited outright). ${ }^{50}$ It is only to say that, as Justice Kennedy implicitly acknowledges, the existence of a right to liberty places a burden on the government to justify any regulations of liberty as necessary and proper. Wrongful behavior that violates the rights of others may justly be prohibited without violating liberty rights—although "wrongful" is not the same as "immoral."

Second, and closely related, the Lawrence majority's position, judicial conservatives say, rejects any moral content of law. That is false. As was just explained, wrongful behavior that violates the rights of others may justly be prohibited without violating the liberty rights of

\footnotetext{
${ }^{49}$ See Randy E. Barnett, The Proper Scope of the Police Power, 79 Notre Dame Law REVIEW (forthcoming).

${ }^{50}$ See id. I discuss the original meaning of the power "to regulate" in Randy E. Barnett, The Original Meaning of the Commerce Clause. 68 U. CHI. L. Rev. 101, 139-46 (2001); id. New Evidence of the Original Meaning of the Commerce Clause, 55 ARK. L. Rev. 847, 863-65 (2003).
} 
others. Because it is usually (but not always ${ }^{51}$ ) immoral to wrongfully violate the rights of others, the entirely justified prohibition of wrongful behavior also necessarily prohibits much immoral behavior as well. But not all ostensibly immoral behavior is also unjust or wrongful, as Thomas Aquinas recognized when he wrote:

\begin{abstract}
Now human law is framed for a number of human beings, the majority of which are not perfect in virtue. Therefore human laws do not forbid all vices, from which the virtuous abstain, but only the more grievous vices, from which it is possible for the majority to abstain, and chiefly those that are to the hurt of others, without the prohibition of which human society could not be maintained; thus human law prohibits murder, theft and the like. ${ }^{52}$
\end{abstract}

To the claim that allowing legislatures to prohibit conduct solely because they deem it to be immoral is to grant legislatures an unlimited and therefore tyrannical power, judicial conservatives might respond that the police powers of states are to be constrained by their own constitutions and their own courts, not by federal judges. This response, if made, would be a non sequitur. On the one hand, if state constitutions grant their legislatures a "police power" that includes an unlimited power to prohibit private conduct solely because it is immoral-a dubious claim-that does not make the power any less unlimited or tyrannical. Nor in the face of such a constitutional grant of power would state judges be in any better position than federal judges to constrain their legislatures. If it is inappropriate for federal judges to restrict the asserted constitutional powers of state legislatures, it would be equally inappropriate for state judges to do so.

On the other hand, if the police power of states is not so unlimited and tyrannical as is being claimed, then it is not beyond the "judicial

\footnotetext{
${ }^{51}$ Under emergency situations it may not be immoral to act wrongfully to violate some rights of others. For example, it may not be immoral for a stranded camper to break into an empty cabin for shelter, though the act would still be wrongful and the camper would be liable for the trespass. See Randy E. Barnett, The Structure of LiBERTY: JUSTICE AND THE RULE OF LAW 169-72 (1998). The possible existence of these exceptional circumstances does not refute the normal case in which it is immoral or "bad" to act wrongfully or "unjustly" toward another.

${ }^{52}$ Thomas Aquinas, Summa Theologica, in Great Books of the Western World (Robert Hutchins, ed., 1952), at 232a (emphasis added).
} 
power" of either state or federal judges to hold state legislatures within their limits. Federal judges may do so, of course, only if they have jurisdiction to protect citizens' rights from violation by their own states. Although at the founding this power was lacking, the Privileges or Immunities Clause of the Fourteenth Amendment (which has effectively been folded into the Due Process Clause) gives the federal government such a power..$^{53}$ Judicial conservatives must read the Fourteenth Amendment very narrowly and ahistorically to deprive federal courts of this power of judicial review.

Finally, judicial conservatives repeatedly assert that there is no textual basis for the protection of a general right to liberty. Unlike "privacy," however, "liberty" is mentioned explicitly in the Due Process Clauses of both the Fifth and Fourteenth Amendments, so this is a much harder argument to sustain. The judicial conservative response is to argue that liberty may properly be restricted so long as "due process" is followed. As Justice Scalia wrote in his dissent: "The Fourteenth Amendment expressly allows States to deprive their citizens of liberty, so long as due process of law is provided." ${ }^{54}$ This is textually and historically wrong.

Ever since the founding, "due process of law" has included judicial review to ensure that a law is within the proper power of a legislature to enact. Historical claims to the contrary are extraordinarily weak, relying exclusively (and ahistorically) on the seeming absence of an explicit grant of judicial power in the text. This fails to consider the original meaning of the "judicial power" reposed in the Supreme Court. An examination of the historical record leaves no doubt that the judicial power originally included the power to nullify unconstitutional laws-especially those that exceeded the power of the legislature. ${ }^{55}$

At the federal level, judicial review, which is part of the "due process of law," includes the power to nullify laws that exceed the

\footnotetext{
${ }^{53}$ See Michael Kent Curtis, No State Shall Abridge: The Fourteenth Amendment AND THE BILL OF Rights (1986). I discuss the original meaning and contemporary relevance of the Privileges or Immunities Clause of the Fourteenth Amendment at length in Barnett, The Proper Scope of the Police Power, supra, note 49, and in RESTORING THE Lost Constitution, supra, note 46 , chapters 3 \& 8.

${ }^{54} 123$ S. Ct. at 2491 (Scalia, J., dissenting).

${ }^{55}$ For copious evidence supporting this historical claim, see RESTORING THE LOST Constitution, supra, note 46, chapter 6.
} 
delegated powers of Congress. That is why the Supreme Court in United States v. Lopez ${ }^{56}$ and United States v. Morrison ${ }^{57}$ could properly strike down federal statutes that exceeded the power of Congress under the Commerce Clause. In addition, however, federal power is further constrained by the rights retained by the people-both those few that are enumerated and, as affirmed in the Ninth Amendment, those liberty rights that are unenumerated as well. At the state level, the Privileges or Immunities Clause of the Fourteenth Amendment prohibits states such as Texas from infringing the privileges or immunities of U.S. citizens. Those include both the liberty rights or "immunities" retained by the people, and the positive rights or "privileges" created by the Constitution of the United States. The "due process of law" includes federal judicial review to ensure that this constitutional restriction on the powers of states has not been transgressed.

Judicial conservatives move heaven and earth to excise the Ninth Amendment and the Privileges or Immunities Clause of the Fourteenth Amendment from the text of the Constitution because they think neither is definite enough to confine judges. That charge is only true, however, if one ignores the original public meaning of those provisions at the time of their enactment. Moreover, the Right's disregard of the text of the Constitution when it fails to support its vision of the "Rule of Law" is as much judicial "activism" —if one must use this phrase ${ }^{58}$ - as the Left's disregard of text when it fails to support its vision of "Justice." In either case, judges are substituting for the text something they prefer-here, silence when the Constitution is in fact speaking eloquently.

\section{Conclusion: A Remarkably Simple Ruling}

In the end, Lawrence is a very simple, indeed elegant, ruling. Justice Kennedy examined the conduct at issue to see if it was properly an aspect of liberty (as opposed to license), and then asked the government to justify its restriction, which it failed to do adequately. The decision would have been far more transparent and compelling

${ }^{56} 514$ U.S. 549 (1995).

${ }^{57} 529$ U.S. 598 (2000).

${ }^{58}$ For my definition along with the reasons I have refrained from using this epithet in the past, see Randy E. Barnett, Is the Rehnquist Court an "Activist" Court? The Commerce Clause Cases, 73 U. Colorado L. Rev. 1275 (2002). 
if Kennedy had acknowledged what was really happening (though perhaps that would have lost votes by other justices). Without that acknowledgment, the revolutionary aspect of his opinion is concealed and rendered vulnerable to the ridicule of the dissent. Far better would it have been to more closely track the superb amicus briefs of the Cato Institute, which Kennedy twice cited approvingly, and of the Institute for Justice.

If the Court is serious in its ruling, Justice Scalia is right to contend that the shift from privacy to liberty, and away from the New Dealinduced tension between the presumption of constitutionality and fundamental rights, "will have far-reaching implications beyond this case. ${ }^{\prime \prime 59}$ For example, the medical cannabis cases now wending their way through the Ninth Circuit would be greatly affected if those seeking to use or distribute medical cannabis pursuant to California law did not have to show that their liberty to do so was somehow "fundamental" — and instead the government were forced to justify its restrictions on that liberty. ${ }^{60}$ While wrongful behavior (or license) could be prohibited, rightful behavior (or liberty) could be regulated, provided that the regulation was shown to be necessary and proper.

Although it may be possible to cabin this case to the protection of "personal" liberties of an intimate nature-and it is a fair prediction that that is what the Court will attempt-for Lawrence v. Texas to be constitutionally revolutionary, the Court's defense of liberty must not be limited to sexual conduct. The more liberties the Court protects, the less ideological it will be and the more widespread political support it will enjoy. Recognizing a robust "presumption of liberty" might also enable the court to transcend the trench warfare over judicial appointments. Both Left and Right would then find their favored rights protected under the same doctrine. When the Court plays favorites with liberty, as it has since the New Deal, it loses rather than gains credibility with the public, and undermines its vital role as the guardian of the Constitution. If the Court is true to its reasoning, Lawrence v. Texas could provide an important step in the direction of a more balanced protection of liberty that could find broad ideological support.

\footnotetext{
${ }^{59} 123$ S. Ct. at 2488 (Scalia, J., dissenting).

${ }^{60}$ I should disclose that I represent clients in two such pending cases: United States v. Oakland Cannabis Buyers Cooperative, 532 U.S. 483 (2001) and Raich v. Ashcroft, 248 F. Supp. 2d 918 (N.D. Cal. 2003).
} 
